\title{
Agricultural Output and Economic Growth Nexus in Ghana
}

\author{
${ }^{1}$ T. Mohammed, ${ }^{2 *}$ O. T. Damba and ${ }^{3}$ J. Amikuzuno \\ ${ }^{1}$ AlMaktoum Senior High School, Tamale, Ghana \\ ${ }^{2 *}$ Department of Agricultural Management and Policy, Faculty of Agriculture, Food and Consumer Sciences
} (FoFCS), University for Development Studies, Tamale, Ghana

\begin{abstract}
${ }^{3}$ Department of Food Security and Climate Change, Faculty of Agriculture, Food and Consumer Sciences (FoFCS), University for Development Studies (UDS), Tamale, Ghana Studies (UDS), Tamale, Ghana
\end{abstract}

*Corresponding Author: otahidu@uds.edu.gh

\section{ARTICLE INFO}

\section{Article history:}

Received: June 6, 2020

Received in revised form:

October 13, 2020

Accepted: December 12, 2020

\section{Keywords:}

Agricultural output, Economic

Growth,

Nexus,

Ghana

DOI:

https://doi.org/10.47762/2020.964x.84

\begin{abstract}
This study explored the relationship between agricultural output and economic growth in Ghana from 1960 to 2016 using monthly data on the Gross Domestic Product (GDP), Gross Capital Formation (GCF), agriculture and inflation. Despite several agriculture-led economic growth programmes that have been implemented by successive governments, including the very recent "Planting for Food and Jobs" to create jobs and boost economic growth, the contribution of agriculture sector output to the Ghanaian economy has been on the decline. The estimated results from the Johansen Maximum Likelihood co-integration and the Vector Error Correction Model (VECM) support evidence of a long-run relationship between agricultural output and economic growth in Ghana. Specifically, the co-integration test reveals that agricultural output and economic growth were found to be moving together in the long run. The Granger causality test showed a unidirectional causal relationship running from agricultural value-added to economic growth but no causal flow from general economic growth to agriculture. This indicates that agriculture is still an engine of economic growth in Ghana and hence requires pro-poor policies to address the numerous challenges.
\end{abstract}

\section{INTRODUCTION}

The agricultural sector in most developing countries including Ghana is relevant in terms of food supply, job creation, and provision of raw materials for industrial production and domestic consumption as well as source of foreign exchange earnings from exports of agricultural commodities. The agricultural sector in most developing countries constitute a large share of the workforce and contributes significantly in terms of value addition to national economies. Gollin (2010) and Diao (2010) maintained that improvement in productivity of the sector has the potential of causing general effects and can as well impact on the economic fortune within an economy.

Historical trends indicate that despite the increase in global demand for agricultural products, production figures have been on the decline (Shamsudin, 2010). Despite the relevance of the sector to the socioeconomic development of developing economies like Ghana, there is the need to assess the current relationship between agriculture and economic growth in Ghana especially as the sector has since lost its place to the service and manufacturing sector in 2006. The 
economic prospects of Ghana after independence remained promising as a result of the country`s natural resource endowment consisting of fertile lands. Though the country`s rate of growth has declined recently, it managed to reduce rural poverty through agriculture and upgraded to low-middle-income country (Diao, 2010). The central role of agriculture in Ghana's economy indicates that increase in output of the sector could trigger overall growth of the economy and reduce poverty level. Maintaining high agricultural productivity is not only capable of stimulating aggregate economic growth in the country but also has the potential of reducing severe rural poverty.

Brooks and Loevinsohn (2011) observed that the unpredictable nature of agricultural productivity in Ghana has improved in the past years due to improvement in agricultural research and technology. However, low productivity of the sector coupled with inadequate budget allocated to the sector by government still remains a challenge (Resnick, 2018). A budget share of just $1.3 \%$ to the sector in 2004 is in sharp contrast of the agreed $10 \%$ of all budgets spending by the government as contained in the Maputo Declaration in 2003. Regardless of prioritizing agriculture in driving economic growth in Ghana, there has not been significant increase in output. The economic transition from the extraction of raw materials to the manufacturing and service economies has seen agriculture losing its role as the major contributor to Ghana's GDP to the service sector since the discovery of oil in 2006.

OECD and FAO (2020), defined agricultural output as output sold, holding stock, retained food stock for consumption as well as stock reserved for livestock feed. The agricultural sector output in Ghana decreased in 2010 and has since, inched at a diminishing rate and currently, contributes about $26.67 \%$ to Ghana`s GDP (MoFA, 2016; GSS, 2020). FAO (2015) maintained that agriculture is still important within the national economy as it continues to employ almost half of the national labor force. Although there is a substantial rise in the service sector (44.14\%), there is not much improvement in the growth rate of GDP recently and attest to the fact that agriculture will remain relevant in Ghana`s economic growth (Diao, 2010). However, the question is, can productivity in agricultural sector propel general economic growth in Ghana and vice versa. In an attempt to boost agricultural productivity, various governments have introduced agricultural policies since 1986 dubbed 'Ghana Agricultural Policy: Action Plan Strategies 1986 - 1988 to the current 'Planting for Food and Jobs (PfJ)' with the aim of enhancing productivity and efficiency.

Tsakok and Gardner (2007) criticized most of empirical studies on agricultural and economic growth based on the cross-sectional data for a panel of countries as results are generally spurious. Also, the assumption of an identical production across different countries may be unrealistic as the level of technology may vary in these countries. Tochukwu (2012) employed an OLS technique, by using agricultural development, capital formation, inflation rate and interest rate to investigate the effect of agricultural sector on economic growth and revealed a positive relationship. Results from Awan (2015) showed a negative relationship between agriculture and economic growth in developing countries while a positive relationship in developed countries. Awan and Aslam (2015) earlier found a positive co-integrating relationship between agriculture and economic growth by applying a Johansen cointegration and a Vector Error Correction (VECM) approach during the 1980-2012 period.

Edwins (2017) through a Granger causality test showed a unidirectional causal relationship from agricultural value added to economic growth. Etea and Obodoechi (2018) found a co-integrating relationship between agricultural sector output and economic growth in Nigeria from 1990- 2017 by applying a Johansen cointegration and the Vector Error Correction model as well as the variance decomposition test. Similar to the current study for Ghana, they included the exchange and interest rates. An addition of the exchange and interest rates changes the focus and dimension of the discussion agricultural output and economic growth 
since focus is on the domestic market added to the fact that GDP is in real terms and takes account of any externality. In line with the challenges of crosssectional data in assessing the relationship between agricultural output and economic growth outline by Sertoglu et al. (2017) and Uddin (2015), this study employed a time series approach since the relationship between agriculture and economic growth is best captured overtime.

\section{MATERIALS AND METHODS}

\section{Data}

The study used monthly time series data from 1960 to 2016 on agricultural output, Gross Domestic Product (GDP), Gross Capital Formation (GCF), trade, inflation and labor force in achieving the objectives of this study. Data for the study was sourced from the International Monetary Fund's International Financial Statistics (IFS), the World Bank's World Development Indicators and the Ghana Statistical Service. Data was converted from nominal to real forms. The data was exposed to a number of tests including stationarity and autocorrelation to ensure the suitability of the data for further analysis.

Test

\section{Unit Root Test}

According to Gujarati (2009), time series data are often not stationary, which means that, its mean, variance and covariance are not time invariant. Non-stationary series lead to spurious and misleading results for policy formulation. It is therefore, essential to test for the stationarity of each variable to ascertain the characteristics of the series. The stationarity test for the level of integration of the regressor and regressands. In this paper, we employed three widely applied unit root tests namely Augmented Dickey-Fuller (ADF), Phillips-Perron (PP) (1988) and Kwiatkowski, Phillips, Schmidt and Shin (KPSS) (1992).

Data was tested in level and in for stationarity to determine the order of integration of each variable measured over time using other formal tests. The results of the unit root test as presented in Table 1 indicates that all the variables were non-stationary in levels but stationary at first difference. Therefore, we can conclude that all the selected variables have the same order of integration, $I(1)$.

Table 1: Unit Root Test of the Variables

\begin{tabular}{lccc} 
Variable & ADF & PP & KPSS \\
\hline Level & & & \\
ln GDP & -1.125 & -1.454 & $0.247^{* *}$ \\
$\ln$ agric & -1.754 & -1.441 & $0.540^{* *}$ \\
$\ln$ GCF & -3.060 & -2.988 & $0.464^{* *}$ \\
ln trade & -2.414 & -2.333 & $0.405^{* *}$ \\
ln labour & -0.760 & 2.462 & $0.704^{* *}$ \\
$\ln$ inflation & -2.713 & -4.707 & $0.281^{* *}$ \\
First difference & & & \\
$\Delta \ln$ GDP & $-5.939^{* * *}$ & $-11.433^{* * *}$ & 0.022 \\
$\Delta \ln$ agric & $-9.451^{* * *}$ & $-10.166^{* * *}$ & 0.035 \\
$\Delta \ln$ GCF & $-7.234^{* * *}$ & $-8.226^{* * *}$ & 0.087 \\
$\Delta \ln$ trade & $-3.514^{* *}$ & $-6.606^{* * *}$ & 0.093 \\
$\Delta \ln$ labour & $-4.639^{* * *}$ & $-5.554^{* * *}$ & 0.098 \\
$\Delta \ln$ inflation & $-13.012^{* * *}$ & $-14.756^{* * *}$ & 0.031 \\
\hline
\end{tabular}

Notes: *, **, *** significant at 1\%, 5\% and 10\%. GDP-Gross Domestic Product; GCF-Gross Capital Formation; ADF-Augmented Dickey-Fuller; PP-Phillips-Perron and KPSS-Kwiatkowski, Phillips, Schmidt and 
Shin. ADF and PP critical value are based on MacKinnon one-sided p-values. KPSS critical values are based on Kwiatkowski-Phillips-Shin (1992).

\section{Empirical Model Specification}

\section{Johansen - Jeselius Co-integration Test}

This study employed the Johansen and Juselius (1990) maximum likelihood co-integration concept to determine if there exist a long run equilibrium relationship between the time series variables considered; real GDP, a proxy for economic growth, agricultural output, gross capital formation, labour force and inflation. We estimate the following model:

$\Delta R_{t}=\sum_{j=1}^{n=1} \pi_{j} \Delta r_{t-j}+\pi r_{t-n}+u_{t}$

Where: $R_{t}$ is lag length $k(p \times 1)$ endogenous vector, $\pi_{j}$ is a short-term adjusting coefficient to describe shortterm relationship, $\pi$ is long term shock vector that includes long term information hint in the regression to test those time series variables' whether there exists long term equilibrium relationship or not.

To examine the vector rank that tests how many non-zero characteristic roots exist in the vector, we use the trace statistic test given as;

$\lambda_{\text {trace }}(y)=-T \sum_{i=y+1}^{k} \operatorname{In}\left(1-\hat{\chi}_{i}\right) \ldots \ldots \ldots$

\section{Granger Causality Test}

Having determined the co-integration among variables, we then employed Granger Causality test to indicate the causal direction of the variables. The following models were estimated:

$$
\begin{aligned}
& \Delta \operatorname{lnag}_{t}=\gamma_{11} e c t_{t-1}+\sum_{i=1}^{p} \emptyset_{1 i} \Delta \operatorname{lnag}_{t-i}+\sum_{j=1}^{q} \varphi_{1 j} \Delta \operatorname{lng} \ln _{t-j}+\mu_{1 t} . \\
& \Delta \operatorname{lng} d p_{t}=\gamma_{21} e c t_{t-1}+\sum_{i=1}^{p} \emptyset_{2 i} \Delta \operatorname{lnag}_{t-i}+\sum_{j=1}^{q} \varphi_{2 j} \Delta \operatorname{lng} d p_{t-j}+\mu_{2 t}
\end{aligned}
$$

From the equations (3) and (4), $\gamma_{11}$ and $\gamma_{21}$ are the coefficients that measure the error correction term, ect $t_{t-1}$ while $e c t_{t-1}$ is the error-correction term with lag one, derived from normalized co-integrating vector. The long run causality relationship exists if ect $t_{t-1}$ is significant. The $\Delta$ indicates the first difference explanatory variables. In other words, it represents the variables in the short run form, $\mu_{1 t}$ and $\mu_{2 t}$ are the error term of the respective equations which follow the i.i.d criteria. To test the existence of the causal relationship in eq. (3), the $H_{0}: \varphi_{1 J}=0$ of no causality is tested using the standard Wald test. If we fail to reject the null hypothesis means that there is no causality running from real GDP to agriculture output. Similarly, for eq. (4), if we fail to reject the null hypothesis, $H_{0}: \emptyset_{2 J}=0$ we conclude that there is no causal relationship running from agriculture output to real GDP. In causal analysis, three results are expected, (1) bidirectional causality; both agriculture and real GDP has causal relationship running from each other, (2) one-way causality direction; only one variable causes the other, and (3) no causality; the two variables do not have causality 
direction. The differentiation of the variables considered in this study was necessary since all six variables were not stationary at their level form using all three-unit root test procedures. After the first difference, all variables were stationary which gave credence for co-integration analysis.

\section{RESULTS AND DISCUSSION}

The presence of long-run equilibrium relationship among the time series variables was therefore tested using the Johansen's maximum likelihood cointegration technique.

Having established the order of integration of the variables, it was then appropriate to test for the presence of the long-run relationship, among the variables. In this regard, the Johansen co-integration test based on trace and Maximum Eigen values test statistic was conducted.

Findings from the Johansen co-integration approach showed the presence of three co-integrating equations in the long run at $5 \%$ critical value. This as well as the Johansen's maximum likelihood values are presented in Table 2. Results of the trace and maximum Eigen values confirmed three co-integrating equations leading to the rejection of the null hypothesis in each case. This is justified by comparing the trace statistics and the Maximum Eigen values with their respective critical values. The trace statistic of the first rank $(r=0)$, second rank $(\mathrm{r}=1)$, and third rank $(\mathrm{r}=2)$ were 129.605, 83.697 and 48.121 which are both greater than their corresponding 5\% critical values of 95.754, 69.819 and 47.856 respectively and therefore calls for the rejection of the null hypothesis of no co-integration. Also, the Maximum Eigen statistics of the first three ranks are also greater than their respective $5 \%$ critical values confirming the existence of three co-integration equations among the six variables. This implies that there is a long run relationship between GDP and agricultural output, gross capital formation, trade openness, inflation and labor as explanatory variables in the study area.

\section{Table 2: Johansen Test for Co-integration}

\begin{tabular}{|c|c|c|c|c|c|}
\hline \multirow{2}{*}{$\begin{array}{l}\text { Hypothesis } \\
\text { Ho: } \\
\text { Rank=r }\end{array}$} & \multirow[b]{2}{*}{ Eigenvalue } & \multicolumn{2}{|c|}{ Trace } & \multicolumn{2}{|c|}{ Maximum Eigen } \\
\hline & & Statistic & $\begin{array}{c}5 \% \text { Critical } \\
\text { Value }\end{array}$ & Statistic & $5 \%$ Critical Value \\
\hline 0 & 0.566 & $129.605 *$ & 95.754 & $45.908 *$ & 40.078 \\
\hline 1 & 0.476 & $83.697 *$ & 69.819 & $35.575^{*}$ & 33.877 \\
\hline 2 & 0.292 & $48.121 *$ & 47.856 & $27.584^{*}$ & 18.960 \\
\hline 3 & 0.206 & 29.161 & 29.797 & 12.711 & 21.132 \\
\hline 4 & 0.175 & 15.495 & 16.450 & 10.553 & 14.265 \\
\hline 5 & 0.102 & 3.841 & 5.897 & 3.841 & 5.897 \\
\hline
\end{tabular}

Note: *Rejection of the hypothesis at the 0.05 level

Source: Author`s Estimation (2019).

These co-integration results showed that the set of variables were co-integrated and there exist three linearly independent co-integrating vectors (equations) describing the long-run equilibrium relationships between these variables. As shown in Table 2, based on Johansen's normalization, the three co-integrating vectors (Equations 5, 6 and 7) describing the long-run equilibrium relationship existing between GDP, agricultural output, gross capital formation, trade openness, inflation and labor.; 
$\beta^{\prime}=\left(\begin{array}{c}\beta_{1}^{\prime} \\ \beta_{2}^{\prime} \\ \beta_{3}^{\prime}\end{array}\right)=\left(\begin{array}{cccccc}1 & 0 & 0 & 0.010 & -0.031 & 2.262 \\ 0 & 1 & 0 & -0.125 & -0.433 & 20.869 \\ 0 & 0 & 1 & -0.149 & 0.064 & -4.035\end{array}\right)$

Vector $\beta_{1}$ implies that, GDP, Agric, Inflation and Labour were co-integrated whiles in vector $\beta_{2}$, Trade, Agric, Inflation and Labour are co-integrated and with vector $\beta_{3}$, GCF, Agric, Inflation and Labour were also cointegrated.

For co-integrating vector $\beta_{1}$, the long-run equilibrium relationship given as $\beta_{1}^{\prime} R_{t}$ is;

$$
\begin{array}{r}
\beta^{\prime} R_{t}=r_{1 t} 0.010 r_{4 t}-0.031 r_{5 t}+2.262 r_{6 t} \sim I(0) \ldots \ldots \ldots \ldots \ldots \ldots \ldots \ldots \ldots \ldots \ldots \\
G D P=0.010 \text { Agric }+0.031 \text { Inflation }+2.262 \text { Labour }+u_{t}, \quad u_{t} \sim I(0),
\end{array}
$$

Results as shown in Table 3 below in the first cointegration equation shows the long run relationship between agricultural output, inflation rate and labour force with GDP during the 1960-2016 period. This indicates that in the long run, agricultural output, inflation rate and labour force has a long run relationship with GDP growth in Ghana. This further indicates that, a $1 \%$ change in the Ghana's inflation rate, will in the long run influence GDP growth in Ghana. This associated with Ghana's periods of political instability such as the $1978-1980$ as well as the global food crisis of 2007 and 2010. This finding is supported by a similar result from a study in India by Srikanth et al. (2011) who also found a long run relationship between GDP and agricultural output.

The coefficient of the long run agricultural output was positive indicating a positive relationship between agricultural output and economic growth which conforms to the a priori expectation. The coefficient was 0.010 which is less than one and indicates that agricultural output is inelastic in relation to economic growth (GDP) and hence a unit change in agricultural output leads to less than proportionate change in economic growth in Ghana during the 1960-2016 period. The positive relationship with economic growth indicates that a $1 \%$ increase in agricultural output will bring about 0.010 increase in economic growth, and it is statistically significant at 1 percent level of significance. There is therefore a long run equilibrium relationship between agricultural output and economic growth. The positive effect of agricultural output is no surprise as the sector over the years continues to have a large share of GDP of the three sectors in Ghana even though it is diminishing in recent years. This finding is consistent with that of Awukose (2009) who also discovered a positive long run relationship between agricultural output and economic growth in a panel study involving a number of developing countries.

The coefficient of inflation rate was negative and statistically significant at 5\% and conforms to the $a$ priori expectation. A coefficient was 0.031 implies a $1 \%$ increase in Ghana's inflation leads to a decrease economic growth during the period under study. The negative relationship with the economic growth indicates that a $1 \%$ increase in the rate of inflation in the long run will result to 0.031 decrease in economic growth. A high inflation rate affects the purchasing power which leads to decrease in aggregate demand within an economy. This confirms with Ayyoub et al. (2011) who concluded on the negative effect of increased inflation beyond a threshold level on Pakistan's GDP. The fall in aggregate demand will result in low productivity which subsequently affect GDP growth thus, causing a decline in economic growth in the long run.

The effect of labour on economic growth from the normalized co-integration vectors was found to be positive and statistically significant at 5\%. The coefficient of 2.262 is greater than 1 implying that increase in Ghana's labour force is elastic in relation to economic growth. This further indicates that a $1 \%$ increase in Ghana's labour force will lead to a $23 \%$ increase in Ghana's economic growth. This holds for the growing human and labour force in the country largely attributed to the various agricultural projects and programmes by various governments. Human resource which is imbedded in the labour force is therefore of enormous importance in promoting economic growth in long run especially with skilled labour. 
Table 3: Long-run Co-integration Relationship between GDP, Trade, GCF, Agric, Inflation and Labor in Ghana from 1965-2016.

\begin{tabular}{|c|c|c|c|c|c|}
\hline & Co-integrating Equation & Vector & $\mathbf{S E}$ & $t$-ratio & $p$-value \\
\hline \multirow{6}{*}{1} & $\overline{\text { GDP }}$ & 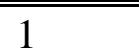 & 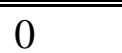 & & \\
\hline & Trade & 0 & 0 & & \\
\hline & GCF & 0 & 0 & & \\
\hline & Agric & 0.010 & 0.028 & -0.370 & $0.002 * * *$ \\
\hline & Inflation & -0.031 & 0.021 & 1.430 & $0.013^{* *}$ \\
\hline & Labor & 2.262 & 1.696 & -1.830 & $0.034 * *$ \\
\hline \multirow{6}{*}{2} & GDP & 0 & 0 & & \\
\hline & Trade & 1 & 0 & & \\
\hline & GCF & 0 & 0 & & \\
\hline & Agric & -0.125 & 0.079 & -1.750 & $0.016^{* *}$ \\
\hline & Inflation & -0.433 & 0.062 & -7.03 & $0.000 * * *$ \\
\hline & Labor & 20.869 & 4.882 & 4.270 & $0.000 * * *$ \\
\hline \multirow{6}{*}{3} & GDP & 0 & 0 & & \\
\hline & Trade & 0 & 0 & & \\
\hline & GCF & 1 & 0 & & \\
\hline & Agric & -0.149 & 0.032 & -4.580 & $0.000 * * *$ \\
\hline & Inflation & 0.064 & 0.025 & 2.52 & $0.012 * *$ \\
\hline & Labor & -4.035 & 1.993 & -2.020 & $0.043 * *$ \\
\hline & $66, p$-value $=0.002 * *)$ & \multicolumn{4}{|c|}{$\begin{array}{c}\beta_{2}\left(\chi^{2}=84.990, p \text {-value }=0.000 * *\right) \\
\beta_{3}\left(\chi^{2}=111.870, p \text {-value }=0.000^{* *}\right)\end{array}$} \\
\hline
\end{tabular}

Note: ** and *** means significant at 5\% and 1\% significance levels respectively; GDP-Gross Domestic Product; GCF-Gross Capital Formation; SE-Standard Error.

Source: Author`s Estimation (2019)

The presence of a long-run co-integration relationship among the variables does not represent a direction in causality. A pairwise Granger causality test within a Vector Error Correction model (VECM) was then carried out to examine the nature of interdependence between agriculture output and economic growth. Findings revealed that the null hypothesis that agricultural value added does not 'Granger-cause' GDP was rejected. This is due to the fact that a probability value of 0.006 is significant at the $1 \%$ level. However, the reverse hypothesis that GDP does not granger cause agric could not be rejected as the probability value of 0.1331 is not significant at all conventional levels. This indicates that there is a unidirectional relationship between Agriculture and economic growth and hence confirms that agriculture contributes significantly to Ghana's economic growth in the short-run. Specifically, the null hypothesis that agriculture does not 'Granger-cause' real GDP could be rejected at the $1 \%$ significant level. However, there is no evidence of the reverse causal flow from economic growth to agriculture and this due to the fact that most of the interventions are largely donor funded. This finding may be a reflection of the so-called 'Dutch Disease' where resources from the agricultural sector are siphoned to the industrial and service sectors. This result is consistent with previous findings for developing countries by Awukose (2008) who all concluded that agricultural value added 'Granger cause' GDP growth. The finding implies that as 
agriculture contributes significantly to economic growth through various means such as the release of surplus labour to other sectors, provision of food and the production of export goods for foreign exchange which in no doubt improves the growth of the economy, there has not been enough support from the general economic growth to further boost agricultural productivity in the country.

There is a bidirectional relationship between GCF and GDP as the two null hypotheses were all rejected. This implies that an improved capital formation can lead to increase in GDP as there will be more loanable funds for the expansion of businesses which adds to aggregate output. Also, as GDP growth improves through increase in aggregate output, income accruing to businesses and for that matter individuals will likely shore up which allows for more capital formation.

Results further showed a unidirectional relation between inflation and GDP as the null hypothesis of no causal flow from inflation to GDP could not be rejected but no causal flow from GDP to inflation could be rejected at $1 \%$ at significant level. This indicates that an increase in GDP has the tendency of causing inflation as the purchasing power of the people would be enhanced, all things being equal. There was also evidence of bidirectional causality between labour and GDP as the two null hypothesis of no causality was rejected at 5\% and 10\% levels. This implies that growth in labor force if appropriately absorbed can lead to an improved GDP growth. On the other hand, increase GDP could transmit to payment of higher wages which can attract more people to join the labour force.

There was a unidirectional causality between Trade and GDP growth. Causal flow existed from trade to GDP as the null hypothesis was rejected at 5\% and this indicate that taking advantage of trade openness through export is likely to improved GDP growth. This confirms findings from Keho (2017) who firms the positive relationship between trade openness and economic growth in the short and long run and the complementary role between trade and gross capital formation towards economic growth. Export brings in foreign exchange which helps drives economic growth as the country can get access to modern technology to increase productivity of goods at a lower cost. However, based on the empirical results, there is no evidence to suggest that economic growth can lead to growth of export value within the country.

\section{Table 4: A Pairwise Granger Causality Tests}

\begin{tabular}{|l|l|l|l|}
\hline Null Hypothesis: & Obs & F-Statistic & Prob. \\
\hline AGRIC does not Granger Cause GDP & 56 & 8.05844 & 0.0064 \\
\hline GDP does not Granger Cause AGRIC & & 2.32715 & 0.1331 \\
\hline GCF does not Granger Cause GDP & 56 & 3.00456 & 0.0888 \\
\hline GDP does not Granger Cause GCF & & 4.62566 & 0.0361 \\
\hline INFLATN does not Granger Cause GDP & 56 & 0.00521 & 0.9427 \\
\hline GDP does not Granger Cause INFLATN & & 8.42757 & 0.0054 \\
\hline LABOR does not Granger Cause GDP & 56 & 5.20399 & 0.0266 \\
\hline GDP does not Granger Cause LABOR & & 3.29629 & 0.0751 \\
\hline TRADE does not Granger Cause GDP & 56 & 4.02961 & 0.0498 \\
\hline GDP does not Granger Cause TRADE & & 1.77068 & 0.1890 \\
\hline
\end{tabular}

Source: Author`s Estimation (2019). 


\section{CONCLUSIONS}

The significance of agriculture to Ghana`s economic growth and development is confirmed by the current study. There is a unidirectional relationship between agricultural output and economic growth due to the export earnings as well as the gross capital formation contribution of the agricultural sector. There exist a strong a strong evidence of the contribution of agriculture to the economic growth of Ghana. While agriculture output and trade openness contribute to Ghana's economic growth, inflationary tendencies have a negative effect on Ghana's economic growth both in the short and long run. Thus, economic growth responds positively to changes from the agricultural sector in Ghana. Increase in agricultural output will result in improved economic growth in the long run with a long run causality between agriculture and GDP growth. Since there exist a long run relationship between GDP and agriculture, more investments from both the private and public sector should be undertaken to enhance agricultural productivity towards economic growth.

\section{ACKNOWLEDGEMENT}

This study forms part of the first author's Master of Philosophy thesis. Funding was not received anywhere during study.

\section{REFERENCES}

Awan, A. G., 2015. Shifting Global Economic Paradigm, Asian Business Review.

Awan, A. G. and Aslam, A., 2015. Impact of agriculture productivity on economic growth: A case study of Pakistan. Global Journal of Management and Social Sciences, 1(1), pp.57-71.

Ayyoub, M., Chaudhry, I.S. and Farooq, F., 2011. Does Inflation Affect Economic Growth? The case of Pakistan. Pakistan Journal of Social Sciences (PJSS), 31(1).
Brooks, S., and Loevinsohn, M., 2011. Shaping agricultural innovation systems responsive to food insecurity and climate change. In Natural Resources Forum (Vol. 35, No. 3, pp. 185-200). Oxford, UK: Blackwell Publishing Ltd.

Diao, X., 2010. Economic Importance of Agriculture for Sustainable Development and Poverty Reduction: Findings from a Case Study of Ghana. International Food Policy Research Institute. Retrieved June 1, 2018 from http://www.oecd.org/agriculture/agriculturalpolicies/46341169.pdf

Edwins, E.O. 2017. Analyzing the causal relationship between agricultural value addition and economic growth in Namibia.

Etea, I. and Obodoechi, D., 2018. Agricultural Output and Economic Growth: The Nigeria Case. Journal of Economic and Sustainable Growth 3.

FAO, 2015. Country fact sheet on food and agriculture policy trends. (2015) (1st ed.). Rome. Retrieved from http://www.fao.org/3/a-i4490e.pdf

Ghana Statistical Service (GSS). 2020. Multidimensional Poverty- Ghana.

Gollin, D. 2010. Agricultural Productivity and Economic Growth. Handbook of Agricultural Economics, vol. 4, pp. 3825 - 3866 .

Gujarati, D. and Porter, D. C. 2009. Basic Econometrics. 5th Ed. New York: McGraw-Hill/Irwin. Johansen, S., and Juselius, S. 1990. 'Maximum Likelihood Estimation and Inference on Co-integration with Application to Demand for Money,' Oxford Bulletin of Economics and Statistics, 52, 169-210.

Keho, Y. 2017. The impact of trade openness on economic growth: The case of Cote d'Ivoire. Cogent Economics \& Finance, 5(1), p.1332820. 
Kwiatkowski, D., Phillips, P.C., Schmidt, P., and Shin, Y. 1992. Testing the Null Hypothesis of Stationarity against the Alternative of a Unit Root, Journal of Econometrics. 54, $159-178$.

Lawal, W. A., 2011. An Analysis of Government Spending on Agricultural Sector and its Contribution to GDP in Nigeria. International Journal of Business and Social Science. 2, 244-250.

Ministry of Food Agriculture (MoFA). 2016. Agriculture in Ghana: Facts and Figures (2015) (1st Ed.). Accra: Ministry of Food and Agriculture. Retrieved May 3, 2018 from http://mofa.gov.gh/site/ OECD and Food and Agriculture Organization of the United Nations. 2020. OECD-FAO Agricultural Outlook 2020-2029. https://doi.org/10.1787/1112c23b$\underline{\text { en }}$

Phillips, P. C. and Perron, P. 1988. Testing for a Unit Root in Time Series Regression Biometrica, 75, 335346.

Resnick, D., 2018. The devolution revolution: Implications for agricultural service delivery in Ghana (Vol. 1714). Intl Food Policy Res Inst.

Sertoglu, K., Ugural, S., and Bekun, F. V., 2017. The contribution of agricultural sector on economic growth of Nigeria. International Journal of Economics and Financial Issues, 7(1).

Shamsudin, M. N., 2010. Economics of Agricultural Innovation: Experiences in Developed Economies and Policy Respond from Malaysia. Paper presented at MAHA International, 3rd December, 2010. Retrieved from

http://www.fama.gov.my/html/themes/fama/document /Kertas_28_MAHA_Econ_Innovation_prof_Mad_Na sir.pdf

Srikanth, P., Sathyanarayana, K. and Director, A., 2011. Co-integration and Causal Relationship between
GDP and Agriculture Sector. CHIEF PATRON CHIEF PATRON.

Tochukwu, O. M., 2012. The Impact of Agricultural Development on Nigeria Economic Growth (19802010) (Doctoral Dissertation, Caritas University).

Tsakok, I. and Gardner, B., 2007. Agriculture in economic development: Primary engine of growth or chicken and egg? American Journal of Agricultural Economics, 89(5): 1145-51.

Uddin, M. M. M., 2015. Causal relationship between agriculture, industry and services sector for GDP growth in Bangladesh: An econometric investigation. Journal of Poverty, Investment and Development, 8 